Received: 20 June 2018

Accepted: 27 April 2019

Published online: 08 May 2019
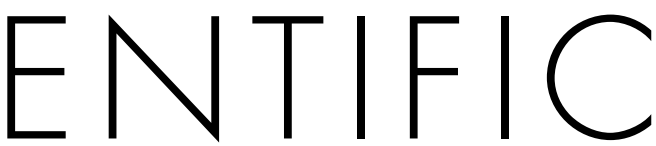

REP
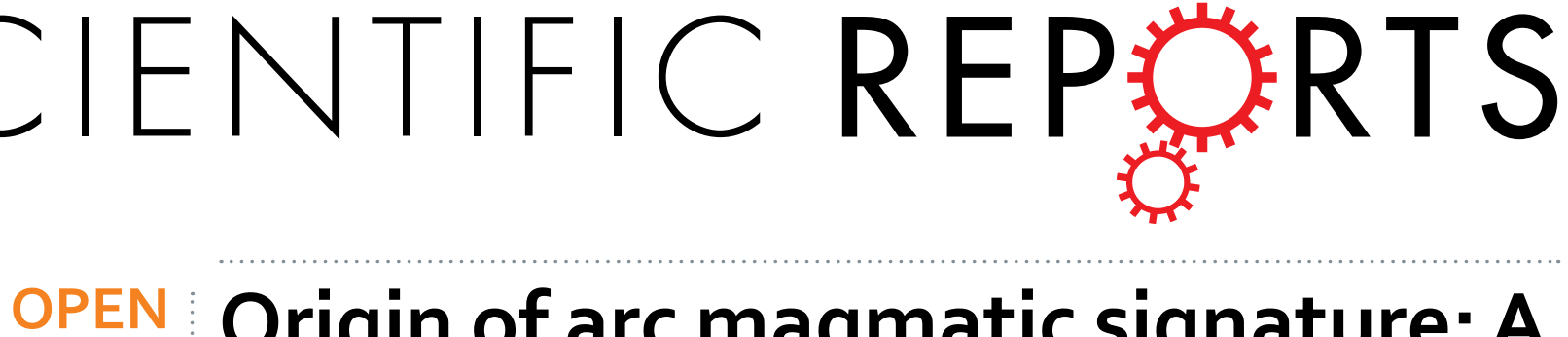

\title{
Origin of arc magmatic signature: $A$ temperature-dependent process for trace element (re)-mobilization in subduction zones
}

\begin{abstract}
Hamed Gamal El Dien ${ }^{1,2}$, Zheng-Xiang Li $\mathbb{1}^{1}{ }^{1}$, Youngwoo Kil ${ }^{3}$ \& Tamer Abu-Alam ${ }^{4}$
Serpentinite is a major carrier of fluid-mobile elements in subduction zones, which influences the geochemical signature of arc magmatism (e.g. high abundances of $\mathrm{Li}, \mathrm{Ba}, \mathrm{Sr}, \mathrm{B}, \mathrm{As}, \mathrm{Mo}$ and $\mathrm{Pb}$ ). Based on results from Neoproterozoic serpentinites in the Arabian-Nubian Shield, we herein report the role of antigorite in the transportation of fluid-mobile elements (FME) and light rare earth elements (LREE) from the subducted slab to arc-related magma during subduction. The serpentinites contain two generations of antigorites: the older generation is coarse-grained, formed at a temperature range of $165-250^{\circ} \mathrm{C}$ and is enriched in $\mathrm{Li}, \mathrm{Rb}, \mathrm{Ba}$ and $\mathrm{Cs}$, whereas the younger generation is finer-grained, formed at higher temperature conditions $\left(425-475^{\circ} \mathrm{C}\right.$ ) and has high concentrations of $\mathrm{B}, \mathrm{As}, \mathrm{Sb}, \mathrm{Mo}, \mathrm{Pb}, \mathrm{Sr}$ and LREE. Magnesite, on the other hand, remains stable at sub-arc depths beyond the stability field of both antigorites, and represents a potential reservoir of FME and LREE for deeper mantle melts. Magnesite has high FME and LREE absorbing capacity (over 50-60\%) higher than serpentine phases. Temperature is the main controlling factor for stability of these minerals and therefore the release of these elements from subducted slabs into arc magmatism. As the liberation of these elements varies along the length of the slab, the resulting cross-arc geochemical variation trend can help to determine the subduction polarity of ancient arcs.
\end{abstract}

Regardless of the tectonic setting in which they form, serpentinites are a major potential carrier of water (up to $15 \%$ ) and incompatible fluid-mobile elements (FME) such as $\mathrm{Li}, \mathrm{B}, \mathrm{As}, \mathrm{Sb}, \mathrm{Pb}, \mathrm{Ba}, \mathrm{Cs}, \mathrm{U}$ and $\mathrm{Sr}^{1-3}$ into the subduction zone and the overlying mantle wedge. Serpentinites can be stable to high temperatures $\left(620^{\circ} \mathrm{C}\right)$ and pressures $(5 \mathrm{GPa})$ at depths of up to $150-200 \mathrm{~km}^{4}$, and their hydration and subsequent dehydration critically influence the generation and chemistry of arc-related magmas ${ }^{5-7}$. Thus, understanding the role of serpentinites (i.e., dehydration/devolatilization) in trace element geochemical cycles in subduction zones can discriminate between arc-related (i.e., high abundances of FME), plume-related, and mid-ocean ridge (MOR) basalts, and can track the cross-arc geochemical variations ${ }^{8}$. Currently, the factors and mechanisms that control the transfer of these elements from oceanic environments through subducting serpentinites to arc magmatism are still unclear.

Numerous in situ studies were previously carried out on serpentinites with the aim of defining the behavior of fluid-mobile elements and rare earth elements (REE) during subduction. These studies highlighted the role of the original minerals (i.e., olivine vs. pyroxene) and temperature on trace element distributions during the subduction process $s^{5,9-12}$ but did not consider the distribution of trace elements at higher-temperature conditions within the stability field of antigorite. Instead, they concentrated on the lizardite/antigorite transition. In addition, they did not provide enough constrains on the temperatures range beyond which FME and REE are uptaken/released from the serpentines to arc magma. Although subducted carbonates are recognized to be a potential source of $C$

\footnotetext{
${ }^{1}$ Earth Dynamics Research Group, The Institute for Geoscience Research (TIGeR) and ARC Centre of Excellence for Core to Crust Fluid Systems (CCFS), School of Earth and Planetary Sciences, Curtin University, GPO Box U1987, Perth, WA 6845, Australia. ${ }^{2}$ Geology Department, Faculty of Science, Tanta University, 31527, Tanta, Egypt. ${ }^{3}$ Department of Energy and Resources Engineering, College of Engineering, Chonnam National University, Yongbong-ro, Buk-gu, Gwangju, South Korea. 'Universitetsbiblioteket, University of Tromsø - The Arctic University of Norway, 9037, Tromsø, Norway. Correspondence and requests for materials should be addressed to H.G.E.D. (email: hamed. gamaleldien@postgrad.curtin.edu.au)
} 
for deep mantle melts through subduction ${ }^{13,14}$, the role of carbonate minerals in serpentinite-bearing rocks as a reservoir for FME and REE has not been adequately considered.

Here, we use the results of a detailed petrological, mineralogical and geochemical study from selected Neoproterozoic serpentinite bodies in the Arabian-Nubian Shield (a typical arc-accretion orogen) ${ }^{15}$ to constrain the role of temperature within the stability field of antigorite on the distribution of FME and REE in subduction zones. In addition to antigorite, mineral chemistry of carbonate minerals indicates that magnesite is a potential reservoir for these elements during the subduction process. Our work argues against the prevailing view that original minerals (olivine and pyroxene) are the main factors controlling the trace element distribution. Instead, we provide evidence for the systematic distribution of FME and REE in subduction zones that depends on temperature conditions of the subducting slab, and we illustrate how the resultant cross-arc geochemical trends may help to determine the subduction polarity of ancient arcs in Earth's history.

Geological background and sample description. The Arabian-Nubian Shield (ANS) represents the largest Neoproterozoic juvenile continental crust. ANS formed through accretion of island arcs to the Gondwanan continental margins by the closure of the Mozambique Ocean during the East-African orogeny (750-550 Ma) ${ }^{16}$. ANS ophiolites (which include abundant serpentinites) mark the suture zones between the accreted $\operatorname{arcs}^{15}$. Egyptian ophiolites, including ultramafic bodies, occur mainly in the central and southern parts of the Eastern Desert, extending across the border with Sudan (Supplementary Fig. S1a). They were intensely deformed in the late Neoproterozoic during oblique collision ${ }^{17}$ and accretion of island arcs onto the Saharan Metacraton, forming ophiolitic mélanges ${ }^{15}$. Although, some ophiolites were previously thought to have formed in mid-ocean ridges $^{18}$, there is a general consensus that the majority of the ANS ophiolites formed in subduction-related tectonic settings ${ }^{15,19-25}$.

Serpentinite samples were collected from Wadi Muweilih in the Central Eastern Desert of Egypt (Supplementary Fig. S1b,c). This area is part of the Um Esh-Um Seleimat tectonic ophiolitic mélange ${ }^{26}$ (Supplementary Fig. S1b), and consists of highly sheared mélange rocks containing many isolated masses of serpentinites, metagabbros, pillowed metabasalts, schistose rocks, metasedimentary rocks including metaconglomerates ${ }^{27}$ (Supplementary Figs S1c, S2a,b). These serpentinized bodies crop out either as large lenticular blocks about1-3km in size, or as small thrust sheets in a tectonic mélange with small amounts of talc-carbonate rocks. The contacts of the serpentinites with metasedimentary and metagabbroic rocks in the east and with metaconglomerates in the west are both SW-dipping thrusts (Fig. S1c). Along the faults, sheared serpentinites have been altered to talc-carbonates.

Petrographic investigations and Raman spectral analyses reveal that the protolith of the studied peridotites was suffered variable degrees of serpentinization and carbonation. Primary minerals olivine and pyroxene are completely serpentinized and chrome-spinel is the only primary relict phase. The studied serpentinites are composed mainly of antigorite, magnesite \pm dolomite, magnetite, small amounts of chrome-spinel, and minor amounts of chlorite and talc (Supplementary Fig. S2d,e). Antigorite exhibits a predominantly a non-pseudomorphic, interpenetrating texture (Fig. 1a-c) and mainly occurs in two distinct crystal sizes: fine aggregate grains $(20-50 \mu \mathrm{m})$ and coarse radiating fibrous $(100-150 \mu \mathrm{m})($ Fig. 1a-c). The fine antigorites commonly overprint the coarse ones (Fig. 1a-c). Magnesite is present in two forms: either as anhedral clusters (Fig. 1d) or in small veinlets associated with fine dolomite (Supplementary Fig. S2c,d). Magnesite, magnetite, chrome-spinel, chlorite and talc occur as randomly distributed grains among antigorite-dominated groundmass.

\section{Results}

Geochemical composition. All the studied serpentinite samples have high-water contents (i.e., high LOI values), ranging from 12.54 to $14.93 \mathrm{wt} \%$ (for details on the bulk-rock compositions see Supplementary Information). The Raman spectra of the examined serpentinite samples identify antigorite as the only serpentine phase (Fig. 1e). Two groupings of antigorite are distinguished based on their different textures (grain sizes) and chemical compositions (Figs. 1 and 2a; Supplementary Table). The first group is coarse-grained $(100-150 \mu \mathrm{m})$, and the second group is finegrained $(20-50 \mu \mathrm{m})\left(\right.$ Fig. 1a-c). The coarse-antigorite (CA) group has higher $\mathrm{SiO}_{2}$ content $(43.01-45.86 \mathrm{wt} \%)$ and lower $\mathrm{Al}_{2} \mathrm{O}_{3}$ content $(0.02-0.97 \mathrm{wt} \%)$ compared to the fine-antigorite (FA) group which range in $\mathrm{SiO}_{2}$ from 39.52$42.95 \mathrm{wt} \%$ and in $\mathrm{Al}_{2} \mathrm{O}_{3}$ from $1.16-3.38 \mathrm{wt} \%$ (Fig. 2a). $\mathrm{MgO}$ and $\mathrm{FeO}$ contents do not show systematic variation between the two groups (Fig. 2a). $\mathrm{NiO}$ (up to $0.92 \mathrm{wt} \%$ ) and $\mathrm{Cr}_{2} \mathrm{O}_{3}$ (up to $1.06 \mathrm{wt} \%$ ) contents show no notable difference, and both groups plot in the serpentine fields of olivine and orthopyroxene, reflecting a harzburgite protolith (Fig. 2b). In situ trace element analyses reveal a heterogeneous distribution of FME between the CA- and FA-groups. FME such as B have higher contents in the FA-group (40.89-49.87 ppm) than in the CA-group (15.32-24.50 ppm), whereas Li has higher contents in the CA-group (3.44-3.95 ppm) than in the FA-group (2.03-2.73 ppm) (Fig. 3; Supplementary Fig. S6, Table). Moreover, the CA-group has lower contents of As, Sb, Pb, Mo, Sr and higher contents of Rb, Cs and Ba (Fig. 3; Supplementary Fig. S6, Table). Th, U, P and high-field strength elements (HFSE: Nb, $\mathrm{Ta}, \mathrm{Zr}$ and $\mathrm{Hf}$ ) show no obvious difference between the two groups, but Ta and Hf show positive spikes compared to elements of the same compatibility in both groups (Fig. 3). REE normalized to (CI)-Chondrite ${ }^{28}$ patterns have a U-shape pattern, and the light rare earth elements (LREE) contents higher in the FA-group ( $\mathrm{La}=0.074-0.127$ ppm, $\left.\mathrm{La}_{\mathrm{N}} / \mathrm{Sm}_{\mathrm{N}}=1.96-3.29\right)$ compared to the CA-group ( $\left.\mathrm{La}=0.031-0.047 \mathrm{ppm}, \mathrm{La}_{\mathrm{N}} / \mathrm{Sm}_{\mathrm{N}}=1.88-2.79\right)$ (Fig. 3). The middle rare earth elements (MREE) to heavy rare earth elements (HREE) show a slight negative slope. The HREE concentrations of the FA and CA- groups are indistinguishable $\left(\mathrm{Yb}_{\mathrm{N} \text { (CI-normalized value) }}=0.47-0.57\right)$ (Fig. 3 ).

Magnesite is the main carbonate mineral, representing 5-10\% of the modal mineral composition in the studied samples, although minor thin veinlets of dolomite also occur (Fig. 1d; supplementary Fig. S2c,d). Magnesite composition varies in $\mathrm{MgO}(37.72-40.49$ wt \%), $\mathrm{FeO}(1.88-5.77$ wt \%) and $\mathrm{MnO}(0.32-2.74$ wt \%). Dolomite has variable contents of $\mathrm{MgO}$ (14.83-20.21 wt \%), $\mathrm{CaO}$ (21.44-27.54 wt \%), FeO (0.44-5.65 wt \%) and $\mathrm{MnO}$ $\left(0.09-1.15\right.$ wt \%). A Primitive Mantle (PM)-normalized ${ }^{29}$ trace element diagram of analysed magnesite shows a significant enrichment in incompatible elements (Fig. 3). Almost all FME, such as Sb (1.55-17.83 ppm), B 

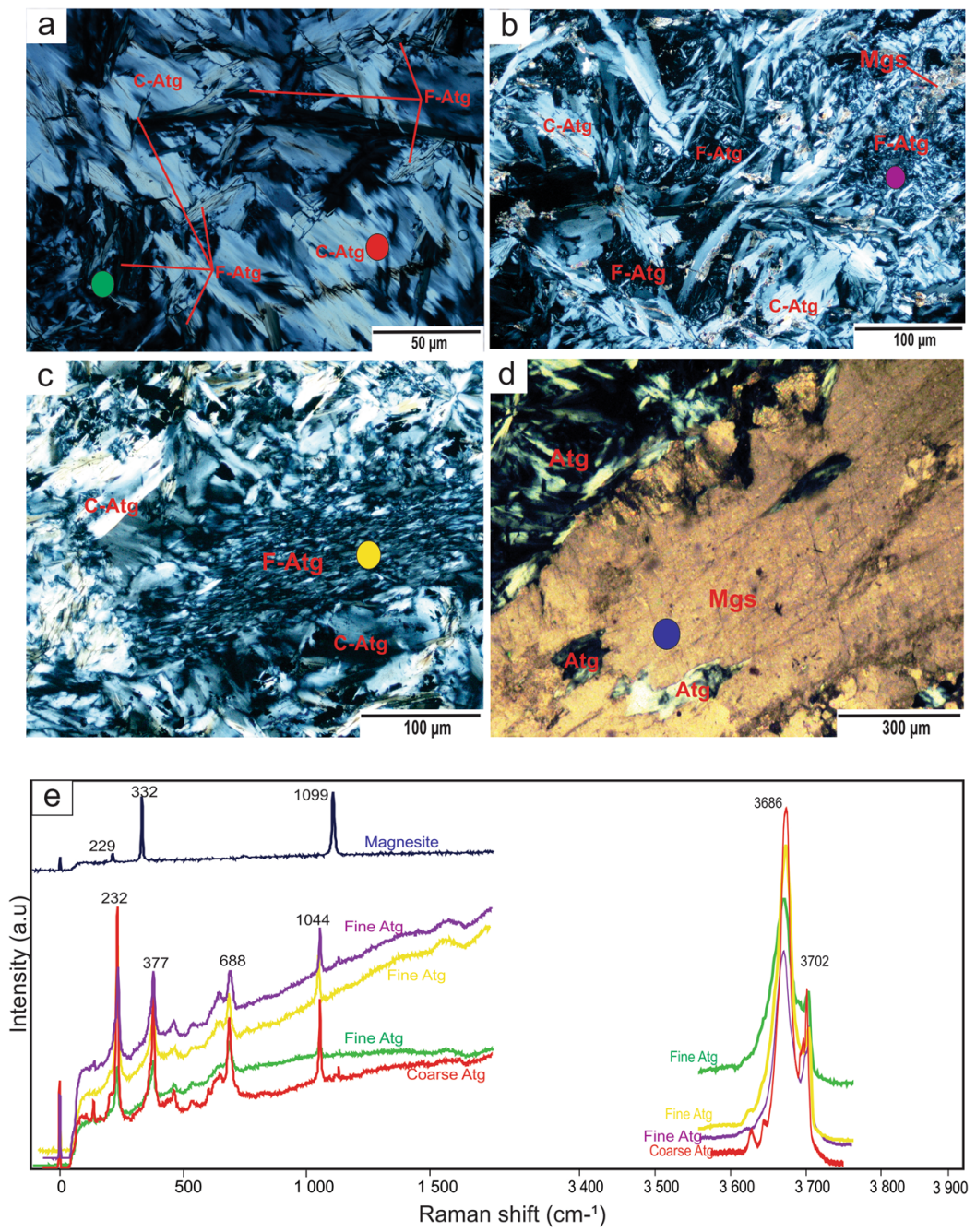

Figure 1. Photomicrographs of the studied serpentinites. (a-c) Interpenetrating texture of antigorite (Atg). (d) Magnesite (Mgs) clast containing antigorite relics. (e) Raman spectra of fine (F) and coarse (C)-grained antigorites in the studied serpentinites in low frequency $\left(0-1500 \mathrm{~cm}^{-1}\right)$ and $\mathrm{OH}$ stretching $\left(3350-3900 \mathrm{~cm}^{-1}\right)$ ranges. Antigorite shows discrete peaks at 232, 377, 688 and $1044 \mathrm{~cm}^{-1}$ in the low wavenumber region and 3686 and $3702 \mathrm{~cm}^{-1}$ in the $\mathrm{OH}$-band region. The Raman spectra of magnesite show peaks at 229, 332 and $1099 \mathrm{~cm}^{-1}$ in the low wavenumber region.

(59.06-170.96 ppm), As (25.31-46.30 ppm), Mo (1.89-2.28 ppm), Cs (0.28-0.72 ppm), Li (13.90-36.01 ppm) and $\mathrm{Pb}(1.63-2.86 \mathrm{ppm})$ are enriched in magnesite (Fig. 3; Supplementary Table). $\mathrm{Rb}(0.70-0.91 \mathrm{ppm})$ is slightly enriched and both $\mathrm{Sr}(5.48-9.04 \mathrm{ppm})$ and $\mathrm{Ba}(0.56-4.32 \mathrm{ppm})$ are slightly depleted relative to primitive mantle but are slightly enriched relative to elements with similar compatibility (Fig. 3). HFSE such as Ti (11.62-20.39 ppm), Zr ( 0.31 ppm), Hf (0.14-0.15 ppm), Nb (0.08-0.09 ppm) and Y (0.57-1.44 ppm) are highly depleted. Chondrite ${ }^{28}$-normalized REE pattern shows the same U-shape like antigorites, but with higher LREE contents $\left(\mathrm{La}_{\mathrm{N}}=5.04-5.80\right)$ (Fig. 3). HREE are highly enriched, with $\mathrm{Yb}$ up to 3 times of that of Chondrite, and show a slight negative slope to MREE.

Thermodynamic modelling. A series of T-X pseudosections at different pressures were calculated to estimate the pressure-temperature conditions of the serpentinization. All the T-X pseudosections show stability of the spinel mineral at high-temperatures $\left(>670^{\circ} \mathrm{C}\right.$; Supplementary Fig. S7). These temperature estimates indicate that the observed spinel in the studied samples is a metastable phase with respect to the surrounded low-grade assemblages $^{30}$. Figure 4 shows two T-X pseudosections at 1 and $8 \mathrm{kbar}$, respectively. These pseudosections have similar topology but dolomite is unstable at low pressure conditions (i.e., $1 \mathrm{kbar}$ ) within the studied T-X range. At higher pressure conditions (i.e., 8 kbar; Fig. 4), however, dolomite is stable within the temperature range of $325-550^{\circ} \mathrm{C}$. The observed mineral assemblages, i.e., chlorite-talc-antigorite-magnesite-fluid \pm dolomite, are thermodynamically stable at the bulk composition range of between $0.15-1$ and $0-1$ for pressures of 1 and $8 \mathrm{kbar}$, respectively (Fig. 4). The upper temperature limits for the stability of the observed assemblages are marked by the anthophyllite-in boundaries. At low pressure conditions (e.g. $1 \mathrm{kbar}$ ), the anthophyllite-in boundaries appear in the temperature range of $360-375^{\circ} \mathrm{C}$, but at $8 \mathrm{kbar}$ the boundaries shift to the higher temperature $\left(450-475^{\circ} \mathrm{C}\right)$. 

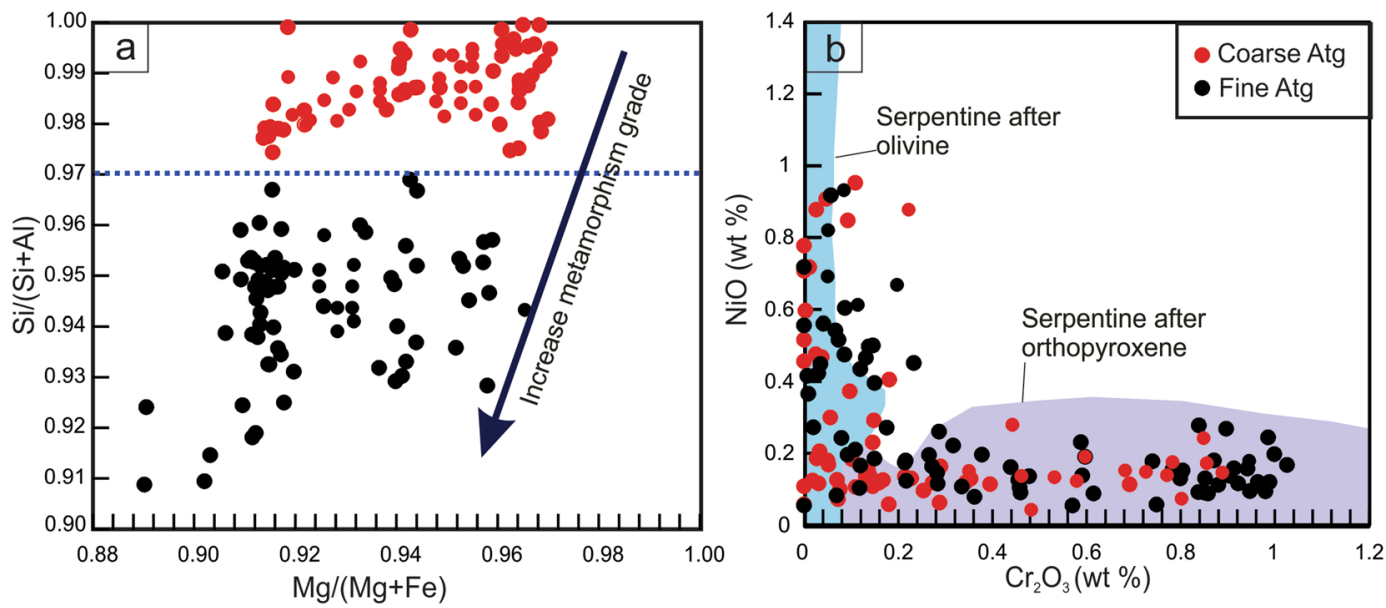

Figure 2. Mineral chemistry of antigorites from the studied samples. (a) $\mathrm{Si} /(\mathrm{Si}+\mathrm{Al}) \mathrm{vs} . \mathrm{Mg} /(\mathrm{Mg}+\mathrm{Fe})$. The variation of $\mathrm{Mg} /(\mathrm{Mg}+\mathrm{Fe})$ indicates different bulk chemistry of the rocks while the variation of $\mathrm{Si} /(\mathrm{Si}+\mathrm{Al})$ is due to increase in the metamorphic grade. (b) $\mathrm{NiO}$ vs. $\mathrm{Cr}_{2} \mathrm{O}_{3}$ (wt \%). Data used to create olivine and orthopyroxene fields collected from Kodolányi et al. ${ }^{12}$.
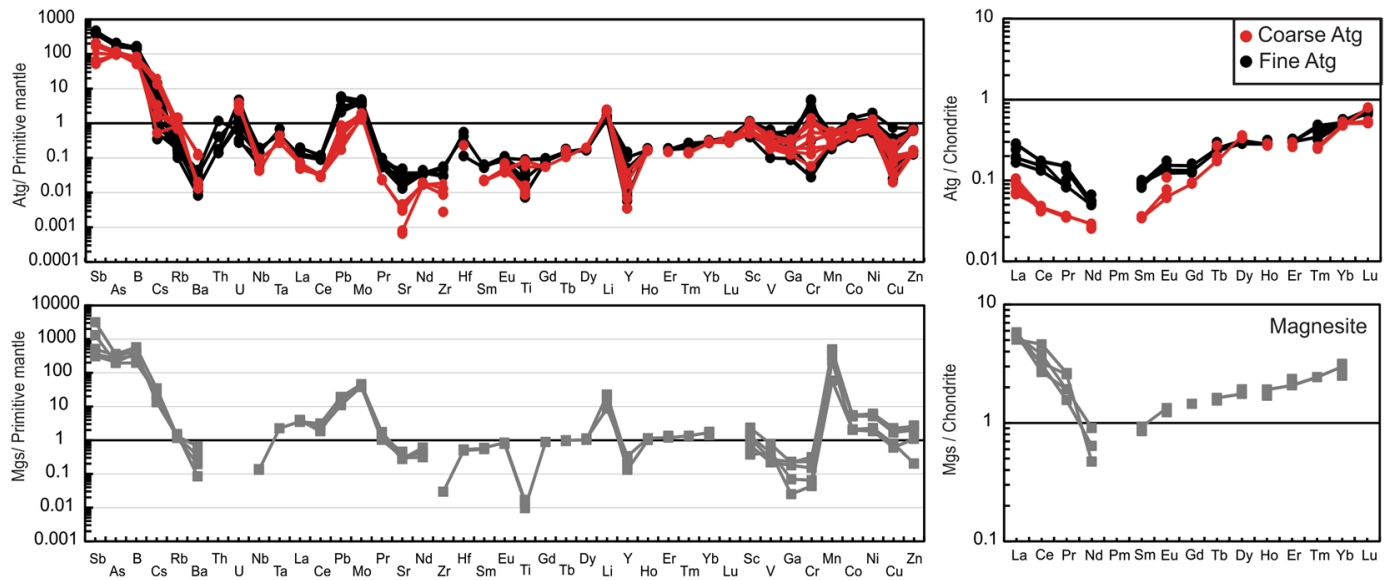

Figure 3. Primitive mantle ${ }^{29}$ normalized multielement and rare earth element patterns normalized to chondrite ${ }^{28}$ of the studied antigorite and magnesite.

Figure 5a shows the shift of anthophyllite-in boundaries toward higher temperature with an increase in pressure from $1 \mathrm{kbar}$ to $9 \mathrm{kbar}$.

The antigorites display an increase in $\mathrm{SiO}_{2}$ content and decrease in $\mathrm{Al}_{2} \mathrm{O}_{3}$ content from the FA-group to the CA-group (Fig. 2a; Supplementary Table). Tschermak's substitution in antigorites is proposed to occur following the equation of $\mathrm{M}^{2+}+\mathrm{Si}^{4+}=\mathrm{Al}^{3+}+\mathrm{M}^{3+}$, where $\mathrm{M}^{2+}$ resides in the octahedral site $\left(\mathrm{Mg}, \mathrm{Fe}^{2+}, \mathrm{Mn}\right.$ and $\left.\mathrm{Ni}\right)$ and $\mathrm{M}^{3+}$ in the tetrahedral site $\left(\mathrm{Fe}^{3+}, \mathrm{Cr}, \mathrm{Al}\right)^{31}$. Thus, $\mathrm{Al}^{3+}$ is incorporated in antigorite through a coupled exchange when one $\mathrm{Mg}$ and one $\mathrm{Si}$ cation are substituted by two $\mathrm{Al}$ cations ${ }^{31,32}$. The $\mathrm{Si} /(\mathrm{Al}+\mathrm{Si})$ ratio of antigorite has been used as a non-linear potential geothermometer for serpentinite rocks, due to its sensitivity to temperature ${ }^{32,33}$. In the current study, the $\mathrm{Si} /(\mathrm{Al}+\mathrm{Si})$ ratios are insensitive to changes in pressure but are sensitive to changes in temperature (Fig. 5).

Although the difference in $\mathrm{Si} /(\mathrm{Al}+\mathrm{Si})$ between the two groups is relatively small (Fig. 5b,c), a gap in the mineralogical composition is clearly observed at $\mathrm{Si} /(\mathrm{Al}+\mathrm{Si}$ ) between 0.965 and 0.975 (Figs. 2a and 5b,c) which corresponds with the petrographic transition from the CA to the FA-group. Also, this gap corresponds with the isopleth line (with value 0.965 ) which is observed in the temperature range of $250-425^{\circ} \mathrm{C}$ (Fig. 5a). The CA-group has $\mathrm{Si} /(\mathrm{Al}+\mathrm{Si})$ in the range of $0.975-1$ (apfu; atoms per formula unit), corresponding with a temperature range of ca. 200 to $250^{\circ} \mathrm{C}$ (Fig. 5). The FA-group has a Si/( $\mathrm{Al}+\mathrm{Si}$ ) content range of $0.92-0.96$ which indicates higher temperature conditions $\left(425-475^{\circ} \mathrm{C}\right)$. Such temperatures cannot be achieved unless the system attains local equilibrium at pressure $>9 \mathrm{kbar}$. 

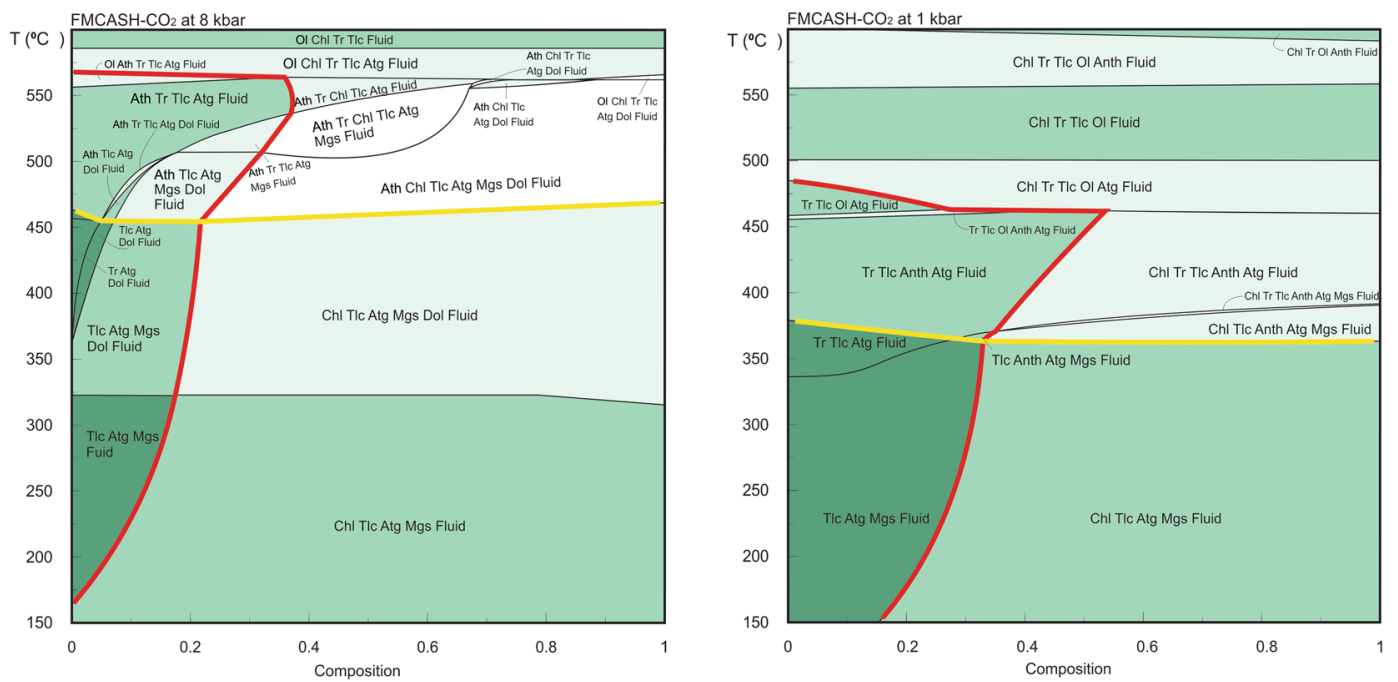

Figure 4. T-X pseudosections. The two pseudosections constructed at pressure $8 \mathrm{kbar}$ and $1 \mathrm{kbar}$ in the chemical system FMCASH- $\mathrm{CO}_{2}$ using the activity models cited in the methods section. The $\mathrm{x}$-axes represent a range of the bulk composition in wt\% where 0 is equivalent to bulk of: $\mathrm{FeO}: 4.157, \mathrm{MgO}: 47.13$, $\mathrm{CaO}: 0.001$, $\mathrm{Al}_{2} \mathrm{O}_{3}: 0.715, \mathrm{SiO}_{2}: 40.524, \mathrm{H}_{2} \mathrm{O}: 8.89, \mathrm{CO}_{2}: 0.001$, and 1 is equivalent to bulk of: $\mathrm{FeO}: 7.00, \mathrm{MgO}: 35.00$, $\mathrm{CaO}: 0.04, \mathrm{Al}_{2} \mathrm{O}_{3}: 3.00, \mathrm{SiO}_{2}: 50.00, \mathrm{H}_{2} \mathrm{O}: 18.00, \mathrm{CO}_{2}: 0.8$. The red isochemical lines represent the chlorite-in boundaries. The studied mineral assemblages are stable to right-side of the chlorite-in boundaries. The yellow line shows the anthophyllite-in boundary. The studied assemblages are stable to the lower temperature part of the anthophyllite-in boundaries.
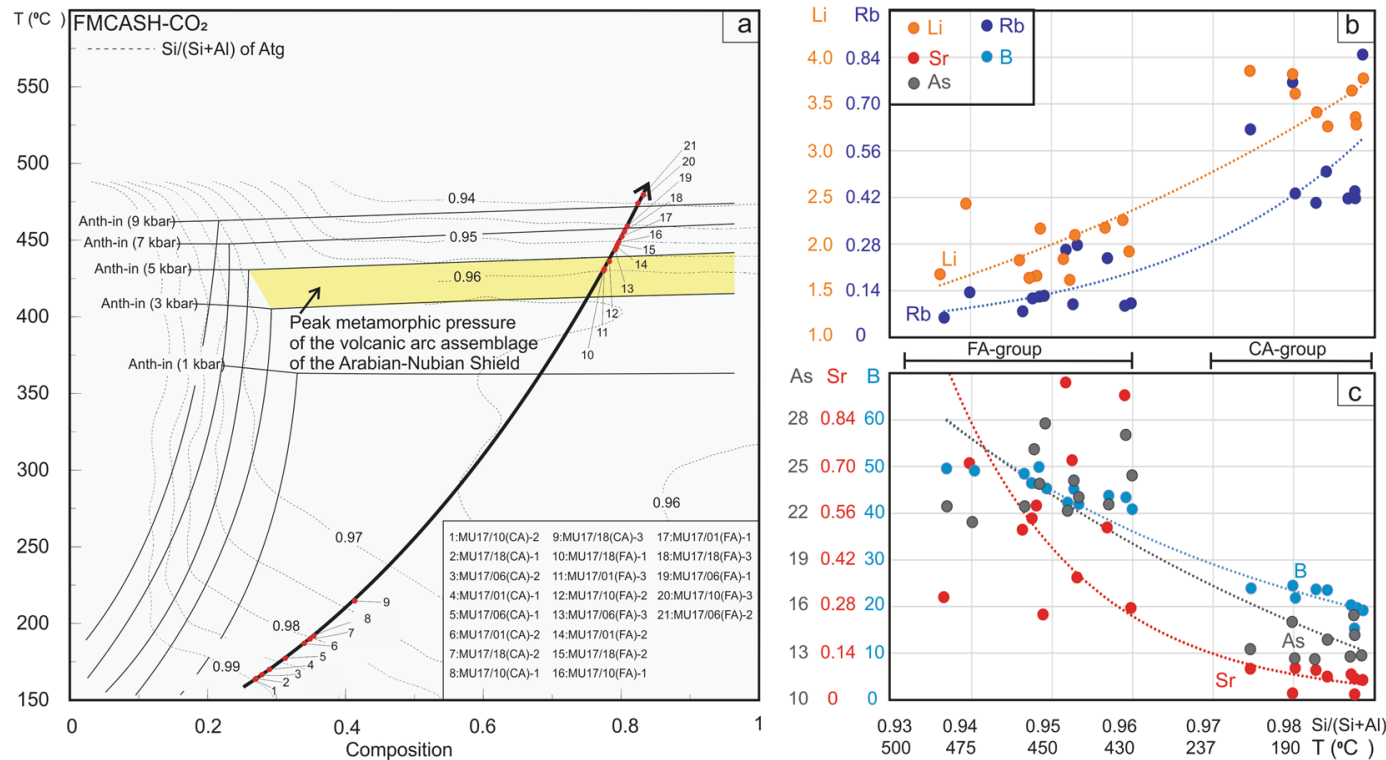

Figure 5. P-T-X pseudosection showing the shift of the anthophyllite-in boundaries toward higher temperature conditions when the pressure increases (a). The yellow area represents the anthophyllite-in boundaries at pressure of ca. $4 \mathrm{~kb}$ ar which is equivalent to the peak metamorphic pressure of the volcanic arc assemblages of the Arabian-Nubian Shield ${ }^{83}$. The pressure represents a combination of lithostatic and hydrostatic pressures. The vertical isochemical solid lines show the shifting in the chlorite-in boundary with pressure change. Contour lines are the $\mathrm{Si} /(\mathrm{Si}+\mathrm{Al})$ ration of the antigorite chemistry in the $\mathrm{T}-\mathrm{X}$ space. The solid black arrow represents the $\mathrm{P}-\mathrm{T}-\mathrm{X}$ path of the studied rocks. The red dots along the P-T-X path represent some of the analysed antigorites (CA at the low temperature conditions) and (FA at the high temperature conditions). The right hand plots shows the variations of $\mathrm{Li}$ and $\mathrm{Rb}(\mathbf{b}) \mathrm{B}, \mathrm{Sr}$ and $\mathrm{As}(\mathbf{c})$ contents of the two group antigorites with the temperature changing along the $\mathrm{P}-\mathrm{T}-\mathrm{X}$ path. The $\mathrm{x}$-axes represents temperature and $\mathrm{Si} /(\mathrm{Si}+\mathrm{Al})$. 


\section{Discussion}

Origin of the protolith. Field, petrographical and geochemical characteristics of the studied serpentinites suggest a subduction channel origin for the protolith. A subduction channel typically consists of fragments of subducted oceanic serpentinites, metasediments, and altered mafic crust that can be later accreted to the arc system to form at mélange zone $e^{34-36}$. Such serpentinites are typically strongly sheared and dominated by antigorite $^{37}$. All of these features are present in the studied region (Supplementary Figs. S1, S2a,b) and most of the ANS ophiolites ${ }^{15}$. The studied serpentinites occur in one of the well-developed suture zones in the Eastern Desert of Egypt, i.e., the Um Esh-Um Seleimat tectonic mélange ${ }^{26}$ (Supplementary Fig. S1b,c). Furthermore, these rocks are similar to some subducted serpentinites in Mesozoic ophiolites such as those of the Zagros suture zone in Iraq ${ }^{38}$ and ophiolite complexes of Northwest Anatolia in Turkey ${ }^{39}$. Previous work (e.g. ${ }^{20,24}$ ) on ophiolites in the vicinity also suggest a subduction-related origin.

The harzburgite protolith of the studied serpentinites suggests that the peridotite parents have a refractory origin, and clinopyroxenes were almost completely exhausted by pre-serpentinization partial melting (for details on the nature of the protolith see Supplementary information). Moreover, mineralogical (spinel $\mathrm{Cr} \#>0.6)^{30}$ and geochemical characteristics such as low $\mathrm{Al}_{2} \mathrm{O}_{3} / \mathrm{SiO}_{2}(\leq 0.04)$, strong depletion in compatible trace elements (i.e., HREE and $\mathrm{Y}$ ), over-enrichment of $\mathrm{As}, \mathrm{Pb}, \mathrm{Mo}$ and nearly flat REE patterns, also point to a subducting-slab origin $^{2,11,34}$ for the studied serpentinites and distinguishes them from mantle wedge/fore-arc serpentinites (e.g., Izu-Bonin-Mariana) ${ }^{12,40}$ (Supplementary Figs. S4, S5).

The high field strength element (HFSE: Nb, Th, Hf and Ti) contents of the studied rocks (Supplementary Fig. S5b) differ significantly from patterns expected of a melt residue ${ }^{41}$. In addition, the absence of any correlation between these elements and LOI indicates that the enrichment processes were not related to the serpentinization; instead, they were more likely caused by melt-rock interaction ${ }^{12,41}$. The high Ti content (150-360 ppm) of the studied serpentinites that plot above the melting trend (Supplementary Fig. S5b) suggests interaction of the subducting serpentinite mainly with Ti-rich melts $(\mathrm{Ti}=30-500 \mathrm{ppm})^{2}$. On the other hand, the positive correlations of LREE and FME with LOI point to the enrichment of these elements during serpentinization process of the protolith through fluid/rock interactions (Supplementary Fig. S3).

Two-stage serpentinization and geochemical consequences. We suggest that the studied rocks experienced two stages of serpentinization which correspond to the different temperature ranges associated with the formation of CA- and FA-group antigorites (Fig. 5). The first stage resulted in the formation of coarse antigorites at $200-250^{\circ} \mathrm{C}$ that may have grown directly from the original olivine and orthopyroxene ${ }^{42}$ during the initial stage of subduction. During this stage, the slab-derived fluids caused strong hydration of the subducted peridotites protolith forming CA-group, such as the antigorite serpentinites $\left(\geq 200^{\circ} \mathrm{C}\right)^{43,44}$ in the Happo-O'ne area in Japan ${ }^{45}$ and some of the other antigorite serpentinites in Eastern Desert, Egypt ${ }^{21,23}$. Although the coarse antigorites could also have crystallized by progressive replacement of lizardite formed during low-temperature oceanic serpentinization ${ }^{43,46}$, we favour the former explanation due to the absences of lizardite relics (i.e., mesh cells $)^{37}$ in the studied serpentinites. The second serpentinization stage occurred at increased subduction depths with elevated metamorphic temperatures of $425-475^{\circ} \mathrm{C}^{10,11}$ (Fig. 5), resulting in the formation of the fine antigorites which overprinted and replaced some of the coarse ones (Fig. 1a-c).

During subduction, oceanic lithosphere gets serpentinized through interactions with circulating fluids released from the subduction channel ${ }^{3,36,37,47-49}$. Although some studies show that the oceanic lithosphere can be serpentinized before it enters the subduction zone ${ }^{50}$, the primitive mantle-normalized pattern of the FME and LREE of the studied serpentinites (Fig. 6) and their rock-forming minerals (antigorites and magnesites) have significant similarity to the subduction inputs components that include mainly altered oceanic crust $(\mathrm{AOC})^{51}$, global subducted sediments (GLOSS II $)^{52}$ and marine sediments ${ }^{53}$. These elements, with the exception of Sr, $\mathrm{Rb}$ and $\mathrm{Li}$, are more highly enriched than seawater-derived hydrothermal fluids in spreading mid-ocean ridges (MOR: Logatchev, Rainbow, Snake Pit) ${ }^{54}$. Moreover, the over-enrichments of As, Sb, B and Mo in the studied serpentinites and their rock-forming minerals support an important role for sediment-derived fluids ${ }^{48,55,56}$ which are characteristic of subduction-related serpentinites ${ }^{2,11,34}$. The similarities in $\mathrm{Li}, \mathrm{Sr}$ and $\mathrm{Rb}$ contents between the serpentinites and seawater-derived hydrothermal fluids suggest contribution of seawater either through direct infiltration into fractures and faults that formed during the bending of a subducted slab ${ }^{57}$ as it entered the subduction channel, or through the circulation of water/fluids in the subduction channel that were released from the subducted oceanic lithosphere and marine sediments ${ }^{58}$.

To further test our interpretation, we calculated the FME composition of the fluids that interacted with the studied rocks during serpentinization. There are only a few experimental studies focused on FME (i.e., B, Li, As, $\mathrm{Sb}$ and $\mathrm{Cs}$ ) partitioning during progressive serpentinization ${ }^{59,60}$ and those studies are limited to the low temperature serpentine phase $\left(200-300^{\circ} \mathrm{C}\right)$. Here we used the partitioning coefficient of those elements ${ }^{59,60}$ to estimate the fluid composition in equilibrium with the CA-group antigorites. The estimated composition of those elements in the equilibrated fluids have $\mathrm{B}=26.41-42.24 \mathrm{ppm}, \mathrm{Li}=0.40-0.46 \mathrm{ppm}, \mathrm{Sb}=0.03-0.09 \mathrm{ppm}, \mathrm{As}=3.26-3.96$ $\mathrm{ppm}$ and $\mathrm{Cs}=0.07-0.23 \mathrm{ppm}$. With the exception of $\mathrm{Li}$, these estimates are similar to the subduction input components compositions of GLOSS II and AOC (e.g. B $=26.6-67.9 \mathrm{ppm}$ and Cs $=0.15-4.9 \mathrm{ppm})^{51,52}$, but are higher than seawater-derived hydrothermal fluids in $\operatorname{MOR}(B=3.35 \mathrm{ppm}, \mathrm{Cs}=0.03 \mathrm{ppm}, \mathrm{As}=0.009 \mathrm{ppm}$ and $\mathrm{Sb}=0.0008 \mathrm{ppm})^{54,61}$. Therefore, we conclude that the studied serpentinites were formed in a subduction-related environment where serpentinization was caused mainly by fluids from the subduction channel with sedimentary input.

The studies of Bebout ${ }^{48}$ and Marschall et al. ${ }^{62}$ demonstrated the release of $\mathrm{B}, \mathrm{Li}, \mathrm{As}, \mathrm{Sb}$ and Cs from sedimentary and mafic rocks via prograde metamorphism and increasing pressure-temperature conditions within the subduction channel. In situ $\mathrm{B}$ and $\mathrm{Li}$ analyses in the studied antigorites indicate, based on thermodynamic modelling (Figs. 4, 5), that the different distributions in B and Li between the two antigorite groups (CA- av. $=21.29$, 

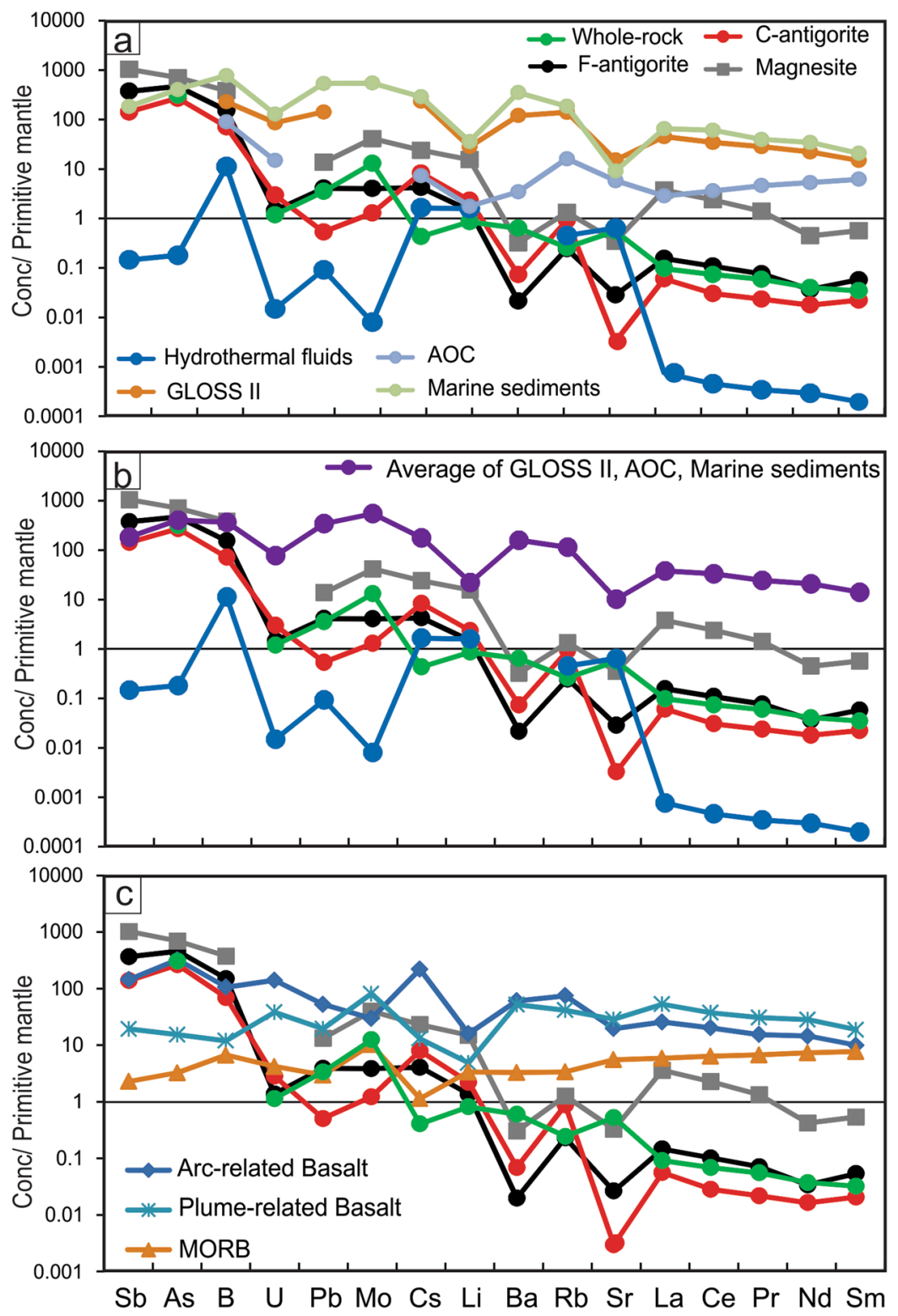

Figure 6. The average contents of fluid-mobile element and light rare earth element patterns of the studied serpentinites and rock forming minerals (antigorite and magnesite) normalized to the Primitive Mantle ${ }^{29}$. (a,b) plotted against the composition of hydrothermal fluids (Logatchev, Rainbow, Snake Pit) ${ }^{54}$ and the contents of subduction inputs including altered oceanic crust $(\mathrm{AOC})^{51}$, global subduction sediments (GLOSS II) ${ }^{52}$ and marine sediments pattern ${ }^{53}$ are reported for comparison; (c) plotted against the average compositions of arcrelated basalts, plume-related basalts and mid ocean ridge basalts (MORB) after Georoc repository (http:// georoc.mpch-mainz.gwdg.de/georoc/).

$3.69 \mathrm{ppm}$, respectively; FA- av. $=45.61,2.30 \mathrm{ppm}$, respectively) (Figs. 5b,c and 6) are related to different temperature conditions. The enrichment of $\mathrm{B}$ at high temperature and $\mathrm{Li}$ at low temperature contrasts with some previous studies ${ }^{2,12,34,63}$ which argue that B enrichment occurs in the low temperature serpentine phase and is depleted at high temperature conditions. However, it is in agreement with the reported retention of B at higher metamorphic grade phase $\mathrm{e}^{5,64}$. Our interpretation is also supported by a continuous loss of $\mathrm{B}$ from the subducting slab (i.e., low B at high temperature) during the progression of subduction ${ }^{48}$. The behaviour of $\mathrm{Li}$, on the other hand, is in agreement with previous studies that revealed the loss of Li during the lizardite/antigorite transition and increasing temperature of serpentinization. Furthermore, $\mathrm{As}, \mathrm{Sb}, \mathrm{Pb}$ and Mo contents are higher in the high temperature FA-group ( $\mathrm{Av}$. As $=23.16 \mathrm{ppm}, \mathrm{Sb}=2.04 \mathrm{ppm}, \mathrm{Pb}=0.61 \mathrm{ppm}, \mathrm{Mo}=0.20 \mathrm{ppm}$ ) compared to the low temperature CA-group ( $\mathrm{Av}$. As $=13.36 \mathrm{ppm}, \mathrm{Sb}=0.77 \mathrm{ppm}, \mathrm{Pb}=0.08 \mathrm{ppm}, \mathrm{Mo}=0.06 \mathrm{ppm}$ ) (Figs. $5 \mathrm{c}$ and 6), suggesting addition/incorporation of those elements to the FA-group at higher temperatures. These trends are consistent with a continuous release of those elements from subducted sediments and from AOC during prograde metamorphism ${ }^{48,56}$. Whereas $\mathrm{B}$, As and $\mathrm{Sb}$ are preferentially incorporated into tetrahedral $\mathrm{Si}$ in sheet silicates ${ }^{5,6}$ 
(i.e., antigorite), they are likely to increase from CA- to FA-group with decreasing $\mathrm{Si} /(\mathrm{Al}+\mathrm{Si})$ and increasing temperature (Fig. 5b,c).

Contrary to the aforementioned elements, large ion lithophile elements (LILE) such as Rb, Ba, Cs and U are more enriched in the low temperature CA-group ( $\mathrm{Av} . \mathrm{Rb}=0.55 \mathrm{ppm}, \mathrm{Ba}=0.48 \mathrm{ppm}, \mathrm{Cs}=0.17 \mathrm{ppm}, \mathrm{U}=0.06 \mathrm{ppm}$ ) than in the high temperature FA-group (Av. $\mathrm{Rb}=0.15 \mathrm{ppm}, \mathrm{Ba}=0.14 \mathrm{ppm}, \mathrm{Cs}=0.08 \mathrm{ppm}, \mathrm{U}=0.02 \mathrm{ppm})$, consistent with the enrichment of these elements at low-temperature conditions ${ }^{2}$ (Figs. 5b, 6). This enrichment suggests the release of these elements during the high-temperature serpentinization process ${ }^{11,12,34}$. However, Sr has higher content in the high temperature FA-group ( $\mathrm{Av} .=0.56 \mathrm{ppm}$ compared to Av $=0.06$ ) indicating continuously addition of $\mathrm{Sr}$ to the antigorite from the subduction channel-derived fluids and retention at higher temperatures. This result is contrary to previous studies that argue against $\mathrm{Sr}$ enrichment at high temperature ${ }^{2,11,12,34,65}$, although those studies concentrated only on lizardite/antigorite transition without determining the formation temperature for each phase or distinguishing between the two temperature-dependant phases of antigorite. Moreover, our results support Kodolányi et al'. ${ }^{12}$ observation that the distribution of B and Sr is controlled by the same mechanisms, which we suggest to be temperature- and fluid-dependent processes.

The REE contents of the serpentine phases are commonly assumed to be an inherited feature from the original minerals (olivine and pyroxene) ${ }^{2,9,11,12}$. Here, the studied antigorite (both the CA- and FA- groups) displays interpenetrating textures with no preservation of the primary minerals, arguing against the role of the parent minerals in the trace element concentrations of antigorite. Although, the two groups have similar HREE contents, the high temperature FA-group have higher LREE $(\mathrm{La}=0.074-0.127 \mathrm{ppm})$ than the low temperature CA-group $(\mathrm{La}=0.030-0.047 \mathrm{ppm})$ (Fig. 6). Our data suggest re-mobilization of LREE with increasing serpentinization temperature.

Carbonates formation and trace element budget. The predominance of magnesite in the studied serpentinites also indicates a paleo-subduction zone origin ${ }^{66}$ as magnesite is rarely found in carbonate-related ultramafic rocks in normal oceanic settings ${ }^{66}$. Magnesite can be formed directly from (1) olivine or orthopyroxene-dominated ultramafic rocks (i.e., $\left.\mathrm{Ol}+2 \mathrm{CO}_{2 \mathrm{aq}}=2 \mathrm{Mgs}+\mathrm{SiO}_{2}\right)^{66,67}$ or by (2) replacing antigorite $\left(2 \mathrm{Atg}+3 \mathrm{CO}_{2}=3 \mathrm{Mgs}+\mathrm{Tlc}+3 \mathrm{H}_{2} \mathrm{O}\right)^{23,68}$. We favour the second mechanism for our study because of a complete absence of quartz in the studied samples. This interpretation is supported by (1) the presence of fractures and vienlets of magnesite that crosscut serpentinites and antigorite groundmass (Supplementary Fig. S2c,d), which represent $\mathrm{CO}_{2}$-rich fluids pathways, (2) the presence of antigorite relics inside magnesite clasts (Fig. 1d), (3) the presence of minor talc associated with magnesite (Supplementary Fig. S2d), (4) strong similarities between the trace element patterns of magnesite and antigorite (Fig. 6), and (5) high trace element contents of magnesite over antigorite that support the formation of magnesite at higher temperature and depth $(\sim 60-70 \mathrm{~km})^{68,69}$ compared to the formation condition of antigorite. The carbon may have come from metamorphic decarbonation of subducted sediments ${ }^{13,70}$ as supported by similar FME and LREE patterns between the magnesite and subducted sediments, AOC and marine sediments. The presence of dolomite with magnesite indicates percolation of moderate to high flow of $\mathrm{CO}_{2}$-Mg-rich and Ca-poor fluids from the subducted sediments ${ }^{66,67}$. Generally, $\mathrm{Mg}$-rich and $\mathrm{Ca}$-poor fluids are associated with peridotites when they undergo complete or near-complete serpentiniza$\operatorname{tion}^{67}$. Therefore, we suggest that magnesite formed after antigorites at higher temperatures and depths during subduction.

Although antigorite is the major carrier of trace elements in serpentinite, we note that magnesite has higher contents of FME of $\mathrm{B}, \mathrm{Li}, \mathrm{As}, \mathrm{Sb}, \mathrm{Pb}, \mathrm{Mo}$, Cs and LREE than antigorite and primitive mantle (Figs. 3, 6), which suggests that magnesite is a potential carrier of, as well as, a reservoir for these elements. In addition, magnesite is also a sink for Mn (Fig. 3). On the other hand, magnesite is depleted in $\mathrm{Sr}$, Ba and U. In summary, we suggest that magnesite has high FME and LREE absorbing capacity of over 50-60\% higher than serpentine phases (calculated according to differences in the contents of those elements between magnesite and antigorite). Based on our petrographic observations and previous experimental studies ${ }^{68}$, we argue that magnesite forms as a result of antigorite transformation, where the parent antigorite contributes a considerable amount of FME and LREE to the newly formed magnesite.

Implications for arc magmatism and subduction polarity geochemical fingerprinting. The thermodynamic modelling results (Figs. 4,5) demonstrate that the formation of two types of antigorite is a temperature-dependent process. The first serpentinization stage and formation of coarse antigorite is estimated at $200-250^{\circ} \mathrm{C}$ and the second serpentinization stage and formation of fine antigorite occurred at $425-475^{\circ} \mathrm{C}$ (Fig. 7). According to different FME and LREE contents of the two types of antigorite groups, we suggest that these elements mainly redistributed (uptaken, trapped and released) as a result of varying temperature. During the first serpentinization stage, the LILE such as $\mathrm{Rb}, \mathrm{Ba}$, Cs and $\mathrm{Li}$ and $\mathrm{U}$ are released from the subducted slab at low temperatures $\left(200-250^{\circ} \mathrm{C}\right)$ and shallow depths and incorporated into coarse antigorites (CA). These result are consistent with previous reported high enrichment of LILE in fluids released from subducting slabs at shallow depths and lower temperatures $\left(200^{\circ} \mathrm{C}\right)$ directly beneath the forearc region ${ }^{48,71}$. The second serpentinization stage is represented by the release of higher amounts of $\mathrm{B}, \mathrm{As}, \mathrm{Sb}, \mathrm{Mo}, \mathrm{Pb}, \mathrm{Sr}$ and LREE from the subducting slab at higher temperatures $\left(425-475^{\circ} \mathrm{C}\right)$ and greater depths, and their incorporation into the fine antigorites (FA) (Fig. 7).

Finally, we suggest that serpentinites remain stable at high sub-arc depths and represent a potential carrier of FME such as B, As, $\mathrm{Sb}, \mathrm{Sr}, \mathrm{Mo}, \mathrm{Pb}$ and LREE that get recycled back into the mantle wedge through the so-called "antigorite breakdown" $\left(600-700^{\circ} \mathrm{C}\right)^{4}$. The similarities of the FME (B, As, Sb, and Li) patterns between the studied serpentinites (including rock forming minerals) and volcanic arc basalts (Fig. 6c) demonstrate how dehydration of serpentinites during subduction plays a principle role in the generation of arc-related magmatism (Fig. 7), in addition to the commonly considered dehydration of subducted sediments and $\mathrm{AOC}^{48,62}$. The high enrichment of these elements in the arc-related basalts can therefore be used to distinguish them from non-arc basalts such as 


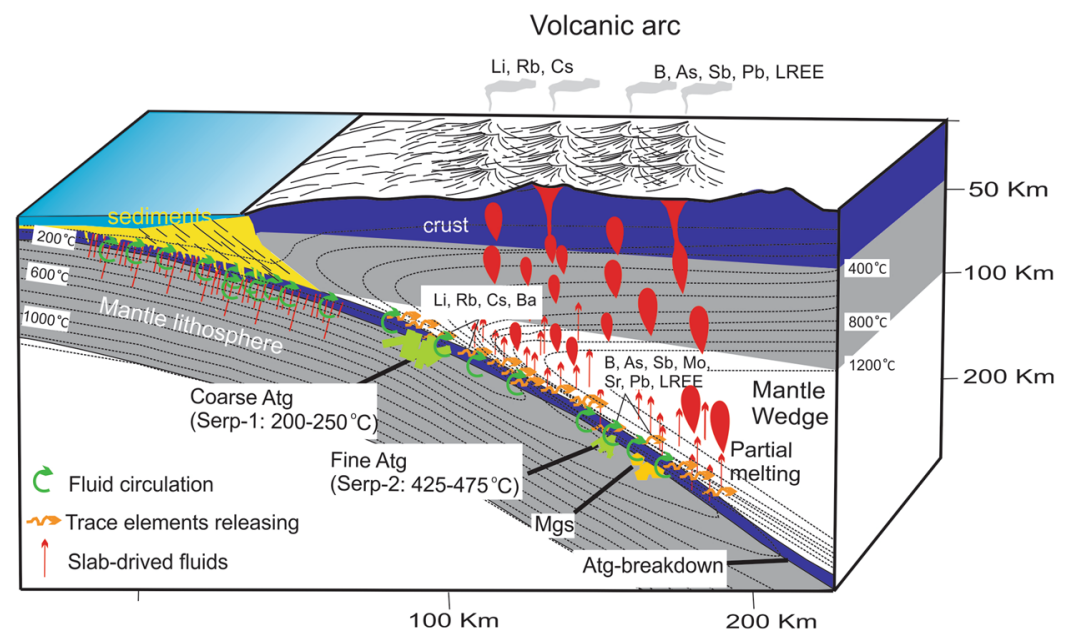

Figure 7. A cross-section sketch of a subduction zone complex showing the position of the first serpentinization stage (Serp-1) and formation of coarse antigorites (Atg) at $200-250^{\circ} \mathrm{C}$, the second serpentinization stage (Serp-2) and formation of fine antigorites at $425-475^{\circ} \mathrm{C}$ and magnesite formation (Mgs).

plume-related basalt and MORB. The model also predicts that arc magmatism closest to the trench should have higher LILE such as $\mathrm{Li}, \mathrm{Rb}$ and $\mathrm{Cs}$, released during the first serpentinization stage, whereas those landward from the trench should be more enriched in $\mathrm{B}, \mathrm{As}, \mathrm{Sb}, \mathrm{Pb}$ and $\mathrm{LREE}$, released during the second serpentinization stage and after antigorite breakdown ${ }^{4}$. Such a cross-arc geochemical variation pattern has indeed been reported in some previous studies of arc volcanic rocks ${ }^{72,73}$. This cross-arc FME and LREE variation pattern, along with previously reported $\mathrm{K}_{2} \mathrm{O} / \mathrm{SiO}_{2}$ cross-arc variation pattern ${ }^{74}$, can be powerful tools for the identification of subduction polarities of ancient arc systems.

\section{Methods}

Raman spectroscopy analysis. Raman spectra of serpentines and carbonates (Fig. 1e) were obtained by a micro-Raman system (HORIBA Jobin Yvon, Lab-RAM HR-800) equipped with a $514 \mathrm{~nm} \mathrm{Ar}^{+}$laser (melles Griot, 43 series Ion Laser, 543-GS-A02) and an optical microscope (Olympus, BX41) at Kanazawa university, Japan. The $\mathrm{Ar}^{+}$laser has an irradiation power at $50 \mathrm{~mW}$ with a spectral resolution of about \pm 2.5 to $\pm 3.5 \mathrm{~cm}^{-1}$. The Raman signal was acquired between 50 and $120 \mathrm{sec}$. Scattered light was collected in a backscattered geometry, using a pinhole $(300 \mu \mathrm{m})$, slit $(100 \mu \mathrm{m})$ and a grating $(600$ groves $/ \mu \mathrm{m})$. A Si-based CCD (charge-coupled device) was used to record the Raman spectra. Based on $\mathrm{OH}$ stretching mode regions and lattice vibrational modes of the serpentine species $^{75}$, the spectral regions ( 0 to $1500 \mathrm{~cm}^{-1}$ and 3400 to $3900 \mathrm{~cm}^{-1}$ ) were investigated. The LabSpec software was used to determine the band position of each spectrum.

Bulk rock chemical analysis. Major and trace element bulk-rock geochemistry was carried out for 8 serpentinite samples (Supplementary Table; all whole-rock data is reported on a volatile-free basis). Whole-rock samples were crushed with a polyethylene-wrapped hammer into $<0.5 \mathrm{~cm}$ pieces and then were ground with ethyl alcohol in an agate mill to a grain size below $50 \mu \mathrm{m}$. Major element compositions were analysed by X-ray fluorescence spectrometer (Shimadzu, XRF-1800) at the Pukyong National University, South Korea. Analytical conditions were $40 \mathrm{kV}$ accelerating voltage and $70 \mathrm{~mA}$ beam current. Analytical precision is better than $2 \%$ for major elements. All glass beads were analysed three times and the averages were taken. Certified Reference Materials (CRMs), BIR-1 and JG-2, were used to determine the accuracy of the major element compositions. For detailed method for trace and rare earth element analyses see ref. ${ }^{21}$. Analytical values for USGS reference samples (BIR-1 and MUH-1) agree with recommended values within suggested tolerances. The precision of the measurements by repeated analyses of reference samples is better than $\pm 5 \%$ for trace elements.

Electron probe micro analysis (EMPA). Major and some minor elements in antigorites and carbonates were acquired using a JEOL JXA-8800 electron-probe at Kanazawa University, Japan (Supplementary Table). The analytical conditions were $15 \mathrm{kV}$ accelerating voltage, $20 \mathrm{nA}$ probe current and $3 \mu \mathrm{m}$ beam diameter. The ZAF-correction was performed to correct the raw data. Ferric and ferrous iron redistribution from electron microprobe analyses was made using the charge balance equation ${ }^{76}$. Natural minerals standards were used for calibration (JEOL Kanazawa STD1) such as Q17-quartz for Si, O16-corundum for Al, O19-eskolaite for Cr, M6-fayalite for Fe, O15-periclase for Mg, O20-manganosite for Mn, M8-wollastonite for Ca, M3-jadeite for Na, M13-KTiPO5 for K, Ti and O24-pentlandite for Ni. Olivine, clinopyroxene and spinel standard reference minerals, separated from Kurose peridotites xenoliths, were used.

Laser ablation-inductively coupled plasma-mass spectrometry (LA-ICP-MS) micro analysis. Trace element compositions of serpentine and magnesite (Supplementary Table) were determined by $193 \mathrm{~nm}$ ArF Excimer LA-ICP-MS at Korean Basic Science Institute (KBSI), South Korea (Teledyne Cetac Technologies equipped with Analyte Excite). Analyses were performed by ablating $110 \mu \mathrm{m}$ diameter spots at $10 \mathrm{~Hz}$ with an 
energy density of $5 \mathrm{~J} / \mathrm{cm}^{2}$ per pulse. Signal integration times were $60 \mathrm{~s}$ for a gas background interval and $60 \mathrm{~s}$ for an ablation interval. The NIST SRM 612 glass was used as the primary calibration standard and was analysed at the beginning of each batch of $<5$ unknowns, with a linear drift correction applied between each calibration. The element concentration of NIST SRM 612 for the calibration is selected from the preferred values of Pearce et al. ${ }^{77}$. Each analysis was normalized using ${ }^{29} \mathrm{Si}$ for serpentine and ${ }^{24} \mathrm{Mg}$ for magnesite as internal standard elements, based on Si and Mg contents obtained by Electron probe micro analysis (EMPA). All minerals were analysed multiple times and the average taken. The relative standard deviations (RSD) of the trace and rare earth elements in the minerals were mostly $5-10 \%$. To improve precision and accuracy of the trace elements data, we analysed the NIST612 CRM before and after each 5 unknown samples. High RSD is found only for ${ }^{137} \mathrm{Ba}(10.7 \%)$. We analysed some clear homogenous areas of antigorite aggregates, but some area may contain dusty magnetite or other minor phases which may influence the actual antigorite trace elements values. Thus, we used the Glitter software, which shows ablation profile for element and permits to reduction of analytical contamination.

Thermodynamic modelling. Thermodynamic modelling was calculated in a $\mathrm{FMCASH}-\mathrm{CO}_{2}$ system (i.e., $\mathrm{FeO}-\mathrm{MgO}-\mathrm{CaO}-\mathrm{Al}_{2} \mathrm{O}_{3}-\mathrm{SiO}_{2}-\mathrm{H}_{2} \mathrm{O}-\mathrm{CO}_{2}$ ). Different pseudosections were constructed using Perple_X $\mathrm{X}^{78}$ and the internally consistent dataset of Holland and Powell ${ }^{79}$. We assumed that local equilibrium, when chemical potentials are equalized ${ }^{80}$, was obtained at a length scale of millimetres. The solution model of (antigorite, chlorite, olivine and garnet, orthopyroxene, clinopyroxene, spinel, carbonate (magnesite) and fluid) ${ }^{32,79,81,82}$ was used. Ideal mixing is assumed for anthophyllite, brucite and talc. Lizardite and chrysotile were used without solution models. Equilibrium thermodynamics is widely used to study the tectonic evolution of the metamorphic rocks ${ }^{79}$. However, for serpentinite where mineralogical change is driven primary by fluid infiltration processes and to a lesser extent by changes in pressure and temperature, the thermodynamic techniques have been applied less commonly. Fluid infiltration process, in general, causes changes in the bulk rock composition, therefore the changes in the bulk chemistry of the system are considered in all the calculated pseudosections. All the major elements of the modelled chemical system show linear relations with the $\mathrm{H}_{2} \mathrm{O}$ content (Supplementary Fig. S3). $\mathrm{Al}_{2} \mathrm{O}_{3}, \mathrm{SiO}_{2}$ and $\mathrm{FeO}$ show negative correlations while $\mathrm{MgO}$ shows a positive correlation. The concentrations of these elements were shifted from the original composition of the rock during partial melting and serpentinization process ${ }^{21}$. For the modelling, the $\mathrm{x}$-axes of the pseudosections are assigned to the composition of the system. The value zero of the $\mathrm{x}$-axes indicates the less modified amounts of the oxides while the value one indicates the maximum modification recorded in the studied rock samples.

\section{References}

1. Kendrick, M. A. et al. Seawater cycled throughout Earth's mantle in partially serpentinized lithosphere. Nat. Geosci. 10, 222-228 (2017).

2. Deschamps, F., Godard, M., Guillot, S. \& Hattori, K. Geochemistry of subduction zone serpentinites: A review. Lithos 178, 96-127 (2013).

3. Rüpke, L. H., Morgan, J. P., Hort, M. \& Connolly, J. A. Serpentine and the subduction zone water cycle. Earth Planet. Sci. Lett. 223, $17-34$ (2004).

4. Ulmer, P. \& Trommsdorff, V. Serpentine stability to mantle depths and subduction-related magmatism. Science 268, 858-61 (1995).

5. Pagé, L. \& Hattori, K. Tracing halogen and B cycling in subduction zones based on obducted, subducted and forearc serpentinites of the Dominican Republic. Sci. Rep. 7, 1-9 (2017).

6. Hattori, K. H. \& Guillot, S. Volcanic fronts as a consequence of serpentinite dehydration in the mantle wedge. Geology 31, 525-528 (2003).

7. Tatsumi, Y. Migration of fluid phases and genesis of basalt magmas in subduction zones. J. Geophys. Res. Solid Earth 94, 4697-4707 (1989).

8. Walowski, K. J., Wallace, P. J., Hauri, E. H., Wada, I. \& Clynne, M. A. Slab melting beneath the Cascade Arc driven by dehydration of altered oceanic peridotite. Nat. Geosci. 8, 404-408 (2015).

9. Deschamps, F. et al. In situ characterization of serpentinites from forearc mantle wedges: Timing of serpentinization and behavior of fluid-mobile elements in subduction zones. Chem. Geol. 269, 262-277 (2010).

10. Deschamps, F., Guillot, S., Godard, M., Andreani, M. \& Hattori, K. Serpentinites act as sponges for fluid-mobile elements in abyssal and subduction zone environments. Terra Nov. 23, 171-178 (2011).

11. Lafay, R. et al. High-pressure serpentinites, a trap-and-release system controlled by metamorphic conditions: Example from the Piedmont zone of the western Alps. Chem. Geol. 343, 38-54 (2013).

12. Kodolányi, J., Pettke, T., Spandler, C., Kamber, B. S. \& Ling, K. G. Geochemistry of ocean floor and fore-arc serpentinites: Constraints on the ultramafic input to subduction zones. J. Petrol. 53, 235-270 (2012).

13. Liu, J., Lin, J.-F. \& Prakapenka, V. B. High-Pressure Orthorhombic Ferromagnesite as a Potential Deep-Mantle Carbon Carrier. Sci. Rep. 5, 7640 (2015).

14. Galvez, M. E. et al. Graphite formation by carbonate reduction during subduction. Nat. Geosci. 6, 473-477 (2013).

15. Stern, R. J., Johnson, P. R., Kröner, A. \& Yibas, B. Neoproterozoic Ophiolites of the Arabian-Nubian Shield. Dev. Precambrian Geol. $13,95-128$ (2004).

16. Johnson, P. R. et al. Late Cryogenian-Ediacaran history of the Arabian-Nubian Shield: A review of depositional, plutonic, structural, and tectonic events in the closing stages of the northern East African Orogen. J. African Earth Sci. 61, 167-232 (2011).

17. Abu-Alam, T. S. \& Stüwe, K. Exhumation during oblique transpression: The Feiran-Solaf region, Egypt. J. Metamorph. Geol. 27, 439-459 (2009).

18. Zimmer, M., Kröner, A., Jochum, K. P., Reischmann, T. \& Todt, W. The Gabal Gerf complex: A precambrian N-MORB ophiolite in the Nubian Shield, NE Africa. Chem. Geol. 123, 29-51 (1995).

19. Azer, M. K. \& Stern, R. J. Neoproterozoic (835-720 Ma) Serpentinites in the Eastern Desert, Egypt: Fragments of Forearc Mantle. J. Geol. 115, 457-472 (2007).

20. Abd El-Rahman, Y. et al. Geochemistry and tectonic evolution of the Neoproterozoic incipient arc-forearc crust in the Fawakhir area, Central Eastern Desert of Egypt. Precambrian Res. 175, 116-134 (2009).

21. Gamal El Dien, H. et al. Neoproterozoic serpentinites from the Eastern Desert of Egypt: Insights into Neoproterozoic mantle geodynamics and processes beneath the Arabian-Nubian Shield. Precambrian Res. 286, 213-233 (2016).

22. Gamal El Dien, H., Hamdy, M., El-ela, A. S. A., Hassan, A. \& Kil, Y. A Window into Neoproterozoic Mantle and its Development: Observations from Ophiolitic Serpentinites in the Eastern Desert of Egypt. Acta Geol. Sin. 89, 22-24 (2015). 
23. Hamdy, M. M. \& Gamal El Dien, H. Nature of serpentinization and carbonation of ophiolitic peridotites (Eastern Desert, Egypt): constrains from stable isotopes and whole-rock geochemistry. Arab. J. Geosci. 10 (2017).

24. Hamdy, M. M., Abd El-Wahed, M. A., Gamal El Dien, H. \& Morishita, T. Garnet hornblendite in the Meatiq Core Complex, Central Eastern Desert of Egypt: Implications for crustal thickening preceding the $~ 600 \mathrm{Ma}$ extensional regime in the Arabian-Nubian Shield. Precambrian Res. 298, 593-614 (2017).

25. Abu-Alam, T. S. \& Hamdy, M. M. Thermodynamic modelling of Sol Hamed serpentinite, south eastern Desert of Egypt: Implication for fluid interaction in the Arabian-Nubian shield ophiolites. J. African Earth Sci. 99, 7-23 (2014).

26. Fowler, A. R. \& El Kalioubi, B. Gravitational collapse origin of shear zones, foliations and linear structures in the Neoproterozoic cover nappes, Eastern Desert, Egypt. J. African Earth Sci. 38, 23-40 (2004).

27. Abu El Ela, A. Contribution to the mineralogy and chemistry of some serpentinites from the Eastern Desert of Egypt. MERC Ain. Shams Univ. Earth Sci. 10, 1-25 (1996).

28. Anders, E. \& Grevesse, N. Abundances of the elements: Meteoritic and solar. Geochim. Cosmochim. Acta 53, 197-214 (1989).

29. McDonough, W. \& Sun, S. The composition of the Earth. Chem. Geol. 120, 223-252 (1995).

30. Arai, S. Characterization of spinel peridotites by olivine-spinel compositional relationships: Review and interpretation. Chem. Geol. 113, 191-204 (1994).

31. Li, X. P., Rahn, M. \& Bucher, K. Serpentinites of the Zermatt-Saas ophiolite complex and their texture evolution. J. Metamorph. Geol. 22, 159-177 (2004)

32. Padrón-Navarta, J. A. et al. Tschermak's substitution in antigorite and consequences for phase relations and water liberation in highgrade serpentinites. Lithos 178, 186-196 (2013).

33. Eggler, D. H. \& Ehmann, A. N. Rate of antigorite dehydration at $2 \mathrm{GPa}$ applied to subduction zones. Am. Mineral. 95, 761-769 (2010).

34. Deschamps, F. et al. Behavior of fluid-mobile elements in serpentines from abyssal to subduction environments: Examples from Cuba and Dominican Republic. Chem. Geol. 312-313, 93-117 (2012).

35. Saumur, B. M., Hattori, K. H. \& Guillot, S. Contrasting origins of serpentinites in a subduction complex, northern Dominican Republic. Bull. Geol. Soc. Am. 122, 292-304 (2010).

36. Blanco-Quintero, I. F., Proenza, J. A., García-Casco, A., Tauler, E. \& Galí, S. Serpentinites and serpentinites within a fossil subduction channel: La Corea mélange, eastern Cuba. Geol. Acta 9, 389-405 (2011).

37. Guillot, S., Schwartz, S., Reynard, B., Agard, P. \& Prigent, C. Tectonic significance of serpentinites. Tectonophysics 646, 1-19 (2015).

38. Aziz, N. R. H., Aswad, K. J. A. \& Koyi, H. A. Contrasting settings of serpentinite bodies in the northwestern Zagros Suture Zone, Kurdistan Region, Iraq. Geol. Mag. 148, 819-837 (2011).

39. Aldanmaz, E. \& Koprubasi, N. Platinum-Group-Element Systematics of Peridotites from Ophiolite Complexes of Northwest Anatolia, Turkey: Implications for Mantle Metasomatism by Melt Percolation in a Supra-subduction Zone Environment. Int. Geol. Rev. 48, (420-442 (2006).

40. Savov, I. P., Ryan, J. G., D’Antonio, M., Kelley, K. \& Mattie, P. Geochemistry of serpentinized peridotites from the Mariana Forearc Conical Seamount, ODP Leg 125: Implications for the elemental recycling at subduction zones. Geochemistry, Geophys. Geosystems 6, n/a-n/a (2005).

41. Paulick, H. et al. Geochemistry of abyssal peridotites (Mid-Atlantic Ridge, $15^{\circ} 20^{\prime} \mathrm{N}$, ODP Leg 209): Implications for fluid/rock interaction in slow spreading environments. Chem. Geol. 234, 179-210 (2006).

42. Muntener, O., Hermann, J. \& Trommsdorff, V. Cooling History and Exhumation of Lower-Crustal Granulite and Upper Mantle (Malenco, Eastern Central Alps). J. Petrol. 41, 175-200 (2000).

43. Evans, B. W. The Serpentinite Multisystem Revisited: Chrysotile Is Metastable. Int. Geol. Rev. 46, 479-506 (2004).

44. Hilairet, N., Daniel, I. \& Reynard, B. Equation of state of antigorite, stability field of serpentines, and seismicity in subduction zones. Geophys. Res. Lett. 33 (2006).

45. Khedr, M. Z. \& Arai, S. Hydrous peridotites with Ti-rich chromian spinel as a low-temperature forearc mantle facies: evidence from the Happo-O'ne metaperidotites (Japan). Contrib. to Mineral. Petrol. 159, 137-157 (2010).

46. Mével, C. Serpentinization of abyssal peridotites at mid-ocean ridges. Comptes Rendus Geosci. 335, 825-852 (2003).

47. Li, Z. X. A. \& Lee, C. T. A. Geochemical investigation of serpentinized oceanic lithospheric mantle in the Feather River Ophiolite, California: Implications for the recycling rate of water by subduction. Chem. Geol. 235, (161-185 (2006).

48. Bebout, G. E. Chemical and Isotopic Cycling in Subduction Zones. Treatise on Geochemistry: Second Edition 15, (Elsevier Ltd., 2014).

49. Gerya, T. V., Stöckhert, B. \& Perchuk, A. L. Exhumation of high-pressure metamorphic rocks in a subduction channel: A numerical simulation. Tectonics 21, 6-1-6-19 (2002).

50. Alt, J. C. et al. The role of serpentinites in cycling of carbon and sulfur: Seafloor serpentinization and subduction metamorphism. Lithos 178, 40-54 (2013).

51. Staudigel, H. Chemical Fluxes from Hydrothermal Alteration of the Oceanic Crust. Treatise on Geochemistry: Second Edition 4, (Elsevier Ltd., 2014).

52. Plank, T. The Chemical Composition of Subducting Sediments. Treatise on Geochemistry: Second Edition 4, (Elsevier Ltd., 2014).

53. Li, Y. H. \& Schoonmaker, J. E. Chemical Composition and Mineralogy of Marine Sediments. Treatise on Geochemistry: Second Edition 9, (2014).

54. Schmidt, K., Koschinsky, A., Garbe-Schönberg, D., de Carvalho, L. M. \& Seifert, R. Geochemistry of hydrothermal fluids from the ultramafic-hosted Logatchev hydrothermal field, $15^{\circ} \mathrm{N}$ on the Mid-Atlantic Ridge: Temporal and spatial investigation. Chem. Geol. 242, 1-21 (2007).

55. Plank, T. \& Langmuir, C. H. Tracing trace elements from sediment input to volcanic output at subduction zones. Nature 362, 739-743 (1993).

56. Gaschnig, R. M. et al. The Molybdenum Isotope System as a Tracer of Slab Input in Subduction Zones: An Example From Martinique, Lesser Antilles Arc. Geochemistry, Geophys. Geosystems 18, 4674-4689 (2017).

57. Faccenda, M., Gerya, T. V. \& Burlini, L. Deep slab hydration induced by bending-related variations in tectonic pressure. Nat. Geosci. 2, 790-793 (2009)

58. Kerrick, D. M. Serpentinite Seduction. Science (80). 298, 1344-1345 (2002)

59. Lafay, R. et al. Experimental investigation of $\mathrm{As}, \mathrm{Sb}$ and $\mathrm{Cs}$ behavior during olivine serpentinization in hydrothermal alkaline systems. Geochim. Cosmochim. Acta 179, 177-202 (2016).

60. Lafay, R. et al. Influence of trace elements on the textural properties of synthetic chrysotile: Complementary insights from macroscopic and nanoscopic measurements. Microporous Mesoporous Mater. 183, 81-90 (2014).

61. Li, Y.-H. A brief discussion on the mean oceanic residence time of elements. Geochim. Cosmochim. Acta 46, 2671-2675 (1982).

62. Marschall, H. R., Altherr, R. \& Rüpke, L. Squeezing out the slab - modelling the release of Li, Be and B during progressive highpressure metamorphism. Chem. Geol. 239, 323-335 (2007).

63. Vils, F., Müntener, O., Kalt, A. \& Ludwig, T. Implications of the serpentine phase transition on the behaviour of beryllium and lithium-boron of subducted ultramafic rocks. Geochim. Cosmochim. Acta 75, 1249-1271 (2011).

64. Scambelluri, M. \& Tonarini, S. Boron isotope evidence for shallow fluid transfer across subduction zones by serpentinized mantle. Geology 40, 907-910 (2012). 
65. Vils, F., Tonarini, S., Kalt, A. \& Seitz, H. M. Boron, lithium and strontium isotopes as tracers of seawater-serpentinite interaction at Mid-Atlantic ridge, ODP Leg 209. Earth Planet. Sci. Lett. 286, 414-425 (2009).

66. Grozeva, N. G., Klein, F., Seewald, J. S. \& Sylva, S. P. Experimental study of carbonate formation in oceanic peridotite. Geochim. Cosmochim. Acta 199, 264-286 (2017).

67. Kelemen, P. B. \& Matter, J. In situ carbonation of peridotite for CO2 storage. Proc. Natl. Acad. Sci. 105, 17295-17300 (2008).

68. Sieber, M. J., Hermann, J. \& Yaxley, G. M. An experimental investigation of C-O-H fluid-driven carbonation of serpentinites under forearc conditions. Earth Planet. Sci. Lett. 496, 178-188 (2018).

69. Poli, S. \& Schmidt, M. W. Petrology of Subducted Slabs. Annu. Rev. Earth Planet. Sci. 30, 207-235 (2002).

70. Kerrick, D. M. \& Connolly, J. A. D. Subduction of ophicarbonates and recycling of CO2 and H2O. Geology 26, 375 (1998).

71. Hyndman, R. D. \& Peacock, S. M. Serpentinization of the forearc mantle. Earth Planet. Sci. Lett. 212, 417-432 (2003).

72. Macdonald, R., Hawkesworth, C. J. \& Heath, E. The Lesser Antilles volcanic chain: a study in arc magmatism. Earth-Science Rev. 49, $1-76$ (2000).

73. Singer, B. S. et al. Along-strike trace element and isotopic variation in Aleutian Island arc basalt: Subduction melts sediments and dehydrates serpentine. J. Geophys. Res. Solid Earth 112 (2007).

74. Gill, J. B. Orogenic Andesites and Plate Tectonics. (Springer Berlin Heidelberg, 1981).

75. Groppo, C., Rinaudo, C., Cairo, S., Gastaldi, D. \& Compagnoni, R. Micro-Raman spectroscopy for a quick and reliable identification of serpentine minerals from ultramafics. Eur. J. Mineral. 18, 319-329 (2006).

76. Droop, G. T. R. A general equation for estimating Fe 3+ concentrations in ferromagnesian silicates and oxides from microprobe analyses, using stoichiometric criteria. Mineral. Mag. 51, 431-435 (1987).

77. Pearce, N. J. G. et al. A Compilation of New and Published Major and Trace Element Data for NIST SRM 610 and NIST SRM 612 Glass Reference. Materials. Geostand. Geoanalytical Res. 21, 115-144 (1997).

78. Connolly, J. A. D. \& Kerrick, D. M. An algorithm and computer program for calculating composition phase diagrams. Calphad 11, $1-55(1987)$.

79. Holland, T. J. B. \& Powell, R. An improved and extended internally consistent thermodynamic dataset for phases of petrological interest, involving a new equation of state for solids. J. Metamorph. Geol. 29, 333-383 (2011).

80. Evans, K. A., Powell, R. \& Frost, B. R. Using equilibrium thermodynamics in the study of metasomatic alteration, illustrated by an application to serpentinites. Lithos 168-169, 67-84 (2013).

81. Jennings, E. S. \& Holland, T. J. B. A Simple Thermodynamic Model for Melting of Peridotite in the System NCFMASOCr. J. Petrol. 56, 869-892 (2015).

82. Connolly, J. A. D. \& Trommsdorff, V. Petrogenetic grids for metacarbonate rocks: pressure-temperature phase-diagram projection for mixed-volatile systems. Contrib. to Mineral. Petrol. 108, 93-105 (1991).

83. Abu-Alam, T. S., Hassan, M., Stuwe, K., Meyer, S. E. \& Passchier, C. W. Multistage Tectonism and Metamorphism During Gondwana Collision: Baladiyah Complex, Saudi Arabia. J. Petrol. 55, 1941-1964 (2014).

\section{Acknowledgements}

We are appreciative of Prof. Abdel Salam Abu El-Ela from Tanta University for support with some rock samples and valuable discussion about the geological and field observations. We are grateful to Prof. T. Morishita and Prof. T. Mizukami from Kanazawa University for their kind assistance to carry out the Electron Microprobe and Raman analyses, respectively. Mr. Nguyen The Cong is thanked for his helping in LA-ICP-MS analyses. Prof. Brendan Murphy and Dr. Josh Beardmore is appreciated for proofreading the paper. Field work was supported by Tanta University, Egypt, which is appreciatively acknowledged. Financial support by the Australian Research Council (grant FL150100133 to ZXL) is acknowledged. This is a contribution to IGCP648: Supercontinent Cycles and Global Geodynamics.

\section{Author Contributions}

H.G. established the idea and was responsible for all the data collection and figures preparation. T.A. performed the thermodynamic modelling and the chemical formula of the minerals. H.G. wrote the manuscript with contributions and revisions by Z.-X.L., Y.K. and T.A.

\section{Additional Information \\ Supplementary information accompanies this paper at https://doi.org/10.1038/s41598-019-43605-9.}

Competing Interests: The authors declare no competing interests.

Publisher's note: Springer Nature remains neutral with regard to jurisdictional claims in published maps and institutional affiliations.

Open Access This article is licensed under a Creative Commons Attribution 4.0 International License, which permits use, sharing, adaptation, distribution and reproduction in any medium or format, as long as you give appropriate credit to the original author(s) and the source, provide a link to the Creative Commons license, and indicate if changes were made. The images or other third party material in this article are included in the article's Creative Commons license, unless indicated otherwise in a credit line to the material. If material is not included in the article's Creative Commons license and your intended use is not permitted by statutory regulation or exceeds the permitted use, you will need to obtain permission directly from the copyright holder. To view a copy of this license, visit http://creativecommons.org/licenses/by/4.0/.

(C) The Author(s) 2019 